\title{
PETROPHYTIC VEGETATION OF THE DONETS RIDGE
}

\author{
Denis KUPRYUSHKIN', Olga DEMINA², Pavel DMITRIEV ${ }^{1}$, Ludmila ROGAL', \\ Vasily CHOKHELI ${ }^{1}$, Vladimir LYSENKO ${ }^{l}$ \\ ${ }^{1}$ Southern Federal University, BolshayaSadovaya str., 105/42, 344006 Rostov-on-Don, Russia \\ ${ }^{2}$ Karachay-Circassian State University of U.D. Aliev, Lenin Street 29, 369202 Karachayevsk, Russia \\ e-mail: vachokheli@sfedu.ru
}

\begin{abstract}
Unique plant habitats are described for the petrophytic communities of the Donets ridge. A scientific basis for the conservation of zonal steppe vegetation and its petrophytic variants is proposed using a number of the characteristic petrophytic communities of Donets ridge as examples. Several criteria of conservation importance are proposed to evaluate the reasons for including the natural territories in the list of protected objects. Recommendations for improving the protection of the steppe petrophyte vegetation of the Donetsk ridge are given. Proposals for creating an ecological network within the studied area have been formulated.
\end{abstract}

Keywords: Protected areas, Donets Ridge, petrophytic communities, Festuco-Brometea, syntaxonomy, vegetation classification.

\section{Introduction}

Having a permanently developing flora, Donets ridge has great importance in the development of the flora of the Don river basin, at least beginning from the Paleogene [37]. This is a unique natural structure wherein many species of relict and endemic plants are conserved. The flora of the Donets ridge rocky territories has been studied in many works [4, 8, 13, 20-22, 26, 4044]. Inventory of subjects for potential protection is a necessary prerequisite for the development of the biodiversity conservation system at both the species and ecosystem levels $[5,33,46]$. Truly rich herbaceous, forb-turfgrass, turfgrass, pelitophytic and petrophytic steppes have been clearly distinguishing on the Donets ridge [6, 13, 27, 28, 39, 48].

Also, three lithological variants of petrophytic or thyme steppe (Steppaepetrophile) and petrophytic vegetation (Petrophyton), viz. calcepetrophyte, psammopetrophytic and xeropetrophytic, were distinguished $[13,17,23]$. Ravine forests are widespread and noted in deep gullies (simplified and simple oak groves) [25, 27, 28]. The southernmost regional sand massif with arena forests and psammophytic vegetation is located in the lower Kundryuchey river basin. Meadow vegetation is represented by the western subtype of meadows of medium moisture in the central floodplain [50].

Within the provincial (in the botanical and geographical sense) division scheme of the Black Sea-Kazakhstan subregion of the steppe region of Eurasia, the studied region is a part of the Black Sea basin, or Pontic province, southern Priazov-Black Sea sub-province. Thus it occupies an important geographical position associated with the sub-provincial border [28, 29].

Black Sea petrophytic steppes are considered as a regional edaphic variant of the steppe type vegetation following the typology accepted in the "Map of the recovered vegetation of Central 
and Eastern Europe" edited by S. A. Gribova and R. Neyheysla [29]. Steppe coenoflora, as well as coenoflora of the petrophyton, are considered as coenoflora of syntaxa of the highest rank, or florocenotypes [7, 35, 36].

In this work, we have distinguished 6 plant associations and proposed several criteria for evaluation of the environmental protection significance of plant communities. Six territories were allocated to give them the status of the specially protected natural territories. Proposals were put forward to create an ecological network in the study area. Recommendations were given on improving the protection of the steppe petrophytic vegetation of the Donetsk Ridge.

\section{Materials and Methods}

\section{Research region}

The study area belongs to the Rostov region, which is located in the south of the East European Plain (Fig.1) comprising the Atlantic-continental steppe region of the zone of temperate latitudes and belongs to the moderately warm agro-climatic region, sub-region of insufficient moisture [27, 28]. The soil cover is comprised of the ordinary and southern chernozems $[2,24,31$, 45, 47].

Extending in its eastern part from the north-west to south-east within the Rostov region, the Donets Ridge has an elevation of about 200-250 m and is criss-crossed by deep ravines and rivers. There are outcrops of rock ridges standing out in the relief and separated by troughs in the form of shallow gullies and by conical rises.

Locating at the East European Plain, the geographical position of the studied region defines the dominance here of a temperate continental climate.

The climate-specific to the Rostov region is the main factor of the formation of the soil and vegetation covers. However, the characteristics of soils and vegetation cover of the Donets Ridge should be considered regarding the specific soil and vegetation combinations related to the relief and soil-forming rock elements [37].

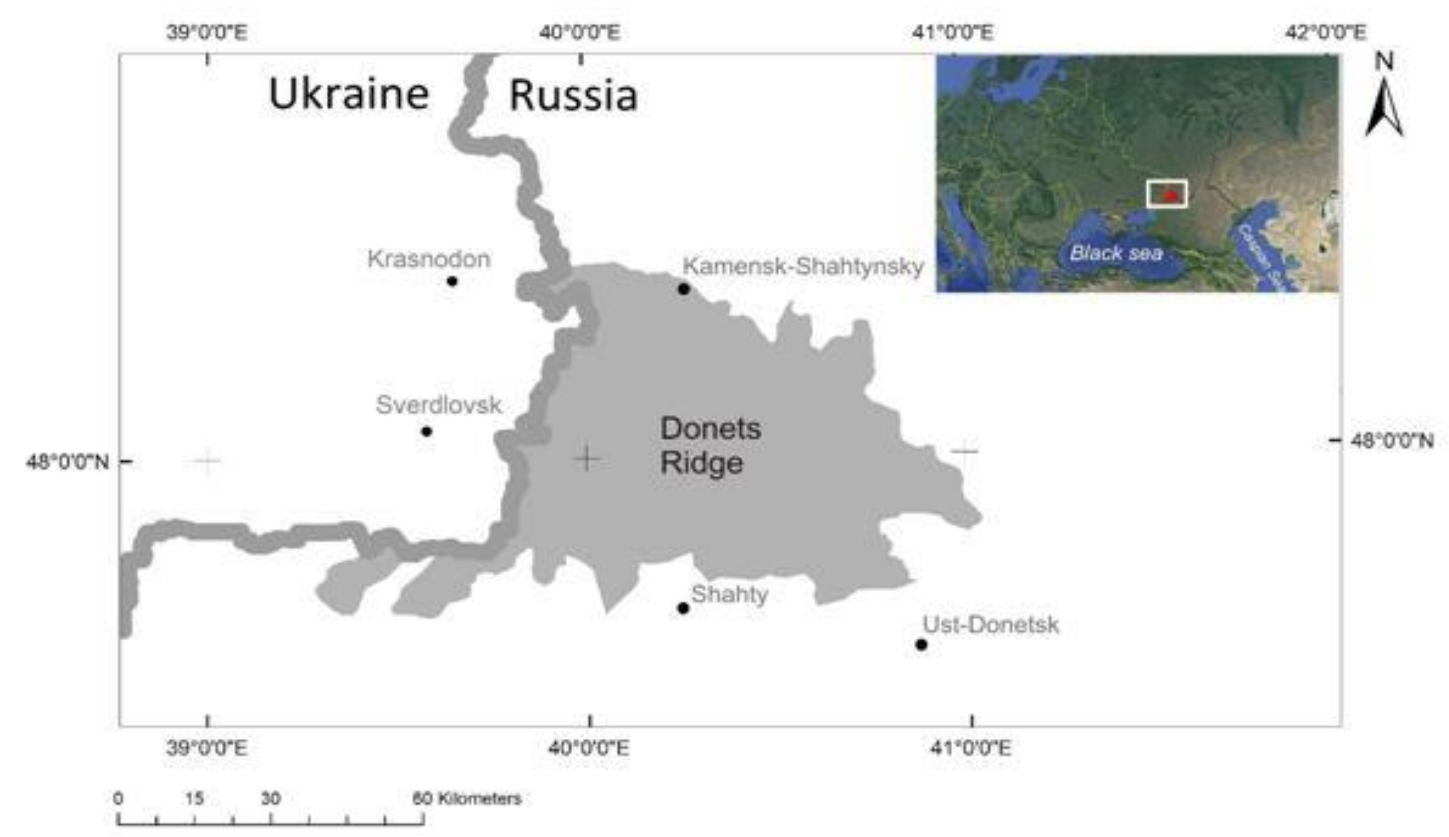

Fig. 1: Location of the study site 
All of this generally defines the landscape of the rugged uplands as a set of highly heterogeneous territorial formations [37, 52].

\section{Research methods}

The work was carried out according to the standard geobotanical techniques $[18,55]$. Geobotanical route reconnaissance, detailed-route, and stationary surveys covered the eastern spurs of the Donetsk Ridge within the Rostov Region. A total of over 100 geobotanical descriptions have been made during the studied period. IBIS [51] and TURBOVEG [14] software packages were applied to process and store the description data with pre-processing in TWINSPAN [16]. Nomenclature of syntaxons was given according to the "International Code of Phytosociological Nomenclature" [49].

The typological and syntaxonomic units of the classification were compared by evaluating the phytocenotic activity of the species of the coenoflora of the described communities [10, 30, 32]. Syntaxonomic description of the flora was based on the Braun-Blanquet methodology [1].

Data processing was performed using DCA (detrended correspondence analysis) methods [15], as well as NMS (or NMDS - nonmetrical multidimensional scaling) method [3] which is included in the PC-ORD [34] and JUICE 7.0.42 program packages [53]. The pre-processing was carried out with the TWINSPAN program [16] applied for the automatic ordering of descriptions and the subsequent data processing using the methods of indirect ordination $[9,11,12,20,21]$.

A method of direct ecological ordination was applied to characterize the local vegetation plots by the environment parameters using ecological scales proposed by L. G. Ramenskiy et al. [38]. The ordination was carried out according to humidification and soil salinity-richness patterns as the most commonly used in geobotanical studies [9, 19-21].

Evaluation of the environmental protection significance of plant communities was based on two main parameters: the trend in the areal reduction (habitat loss) and rarity of the protected elements [33].

\section{Results}

All thyme-supporting communities of the Donetsk Ridge located within the study area were found to gravitate to the Festuco-Brometea Br.-Bl. et Tx. 1943 class, which is a result of their occurrence in the steppe zone. Only one association was included in the Helianthemo-Thymetea vegetation class, which unites the petrophytic vegetation of steppe communities with low aromatic stiff-leaved shrubs and semi-shrubs of the Black Sea region as co-dominants (Table 1).

\section{Associations and high-level syntaxa}

Class Festuco-Brometea Br.-B1. et Tx. 1943

Order Festucetalia valesiacae Br.-Bl. et Tx. 1943

Alliance Festucion valesiacae Klika 1931

Suballiance Phlomenion pungentis Saitov et Mirkin 1991

Association Plantagini urvillei-Stipetum tirsae Demina 2012

Association Stipetum lessingianae Soó 1949

Association Sclerantho annui-Stipetum capillatae Demina 2015

Association Plantagini stepposae-Stipetum pulcherrimae V. S1. 1995 
Association Medicago romanicae-Stipetum zalesskii Demina 2015

Class Helianthemo-Thymetea Romashchenko, Didukh et Solomakha 1996

Order Thymo cretacei-Hissopetalia cretacei Didukh 1989

Order, Alliance?

Association Sileno borysthenicae-Hyssopetum angustifolii Demina 2014

The results of the expert assessment of the environmental protection significance of the Don basin steppe communities are presented in Table 1. They have been obtained using six criteria for the associations selected in the studied region. Criterium A: A(v) 1 - up to $20 \%$ of the persistent species in the geobotanical descriptions; $\mathrm{A}(\mathrm{v}) 2$ - up to $40 \%$ of the persistent species in the geobotanical descriptions; $\mathrm{A}(\mathrm{v}) 3$ - up to $60 \%$ of the persistent species in the geobotanical descriptions; $\mathrm{A}(\mathrm{v}) 4$ - up to $80 \%$ of the persistent species in the geobotanical descriptions. Criterium C: C (I) - priority habitats from the referred as an endangered; C (II) - endangered habitats. Category of rarity R: R0 - wide areal, high occurrence, the large size of phytocenoses, R1 - wide areal, low occurrence, the large size of phytocenoses, R2 - wide areal, high occurrence, small size of phytocenoses, R3 - wide areal, low occurrence, the small size of phytocenoses, R4 narrow areal, high occurrence, the large size of phytocenoses, R5 - narrow areal, low occurrence, the large size of phytocenoses, R6 - narrow areal, high occurrence, the small size of phytocenoses, R7 - narrow areal, low occurrence, small size of phytocenoses. Availability and application of protection $\mathrm{N}$ : $\mathrm{N} 0$ - not protecting, $\mathrm{N} 1$ - protecting by less than $20 \%, \mathrm{~N} 2$ - protecting from $21 \%$ to $50 \%$, N3 - protecting from $51 \%$ to $70 \%, \mathrm{~N} 4$ - protecting more than $70 \%$. Category of protection: 1 - highest - nature reserves (I), 2 - high - sanctuaries, natural parks (II, IV), 3 - medium -natural treasures (III), 4 low -not protecting (0). Floristic-phytocenotic significance F: F1 - very high, F2 - high, F3 - medium, F4 - low.

Table 1: Assessment of the environmental protection significance of the plant communities identified in the studied region

\begin{tabular}{|c|c|c|c|c|c|c|}
\hline Associations $\backslash$ Criteria & $\mathbf{A}$ & $\mathbf{C}$ & $\begin{array}{l}\text { Rarity } \\
\text { category }\end{array}$ & Security & $\begin{array}{l}\text { Protection } \\
\text { category }\end{array}$ & $\begin{array}{c}\text { Floristic- } \\
\text { phytosociological } \\
\text { significance } \\
\end{array}$ \\
\hline \multicolumn{7}{|c|}{ Class Festuco-Brometea } \\
\hline $\begin{array}{l}\text { Plantagini urvillei- } \\
\text { Stipetum tirsae }\end{array}$ & $\mathrm{A}(\mathrm{v}) 2$ & $\mathrm{C}(\mathrm{II})$ & R 3 & $\mathrm{~N} 1$ & 3 (III) & F 2 \\
\hline Stipetum lessingianae & $\mathrm{A}(\mathrm{v}) 1$ & $\mathrm{C}(\mathrm{II})$ & $\mathrm{R} 2$ & $\mathrm{~N} 1$ & 3 (III) & F 2 \\
\hline $\begin{array}{l}\text { Plantaginistepposae- } \\
\text { Stipetumpulcherrimae }\end{array}$ & $A(v) 2$ & $\mathrm{C}(\mathrm{I})$ & R 3 & $\mathrm{~N} 1$ & 3 (III) & F 3 \\
\hline $\begin{array}{l}\text { Medicago romanicae- } \\
\text { Stipetumzalesskii }\end{array}$ & $\mathrm{A}(\mathrm{v}) 1$ & $\mathrm{C}(\mathrm{II})$ & R 2 & $\mathrm{~N} 1$ & 3 (III) & F 2 \\
\hline $\begin{array}{l}\text { Scleranthoannui- } \\
\text { Stipetumcapillatae }\end{array}$ & $\mathrm{A}(\mathrm{v}) 1$ & $\mathrm{C}(\mathrm{II})$ & $\mathrm{R} 2$ & $\mathrm{~N} 1$ & $1(\mathrm{I})$ & F 2 \\
\hline \multicolumn{7}{|c|}{ ClassHelianthemo-Thymetea } \\
\hline $\begin{array}{l}\text { Sileno borysthenicae- } \\
\text { Hyssopetumangustifolii }\end{array}$ & $\mathrm{A}(\mathrm{v}) 4$ & $\mathrm{C}$ (II) & R 7 & $\mathrm{~N} 0$ & $4(0)$ & F 1 \\
\hline
\end{tabular}

Confinement of the communities of plant associations identified in the Donets Ridge area is shown in Fig. 2. Phytocenotic confinement of the rare and endangered plant species is shown in Table 2. 


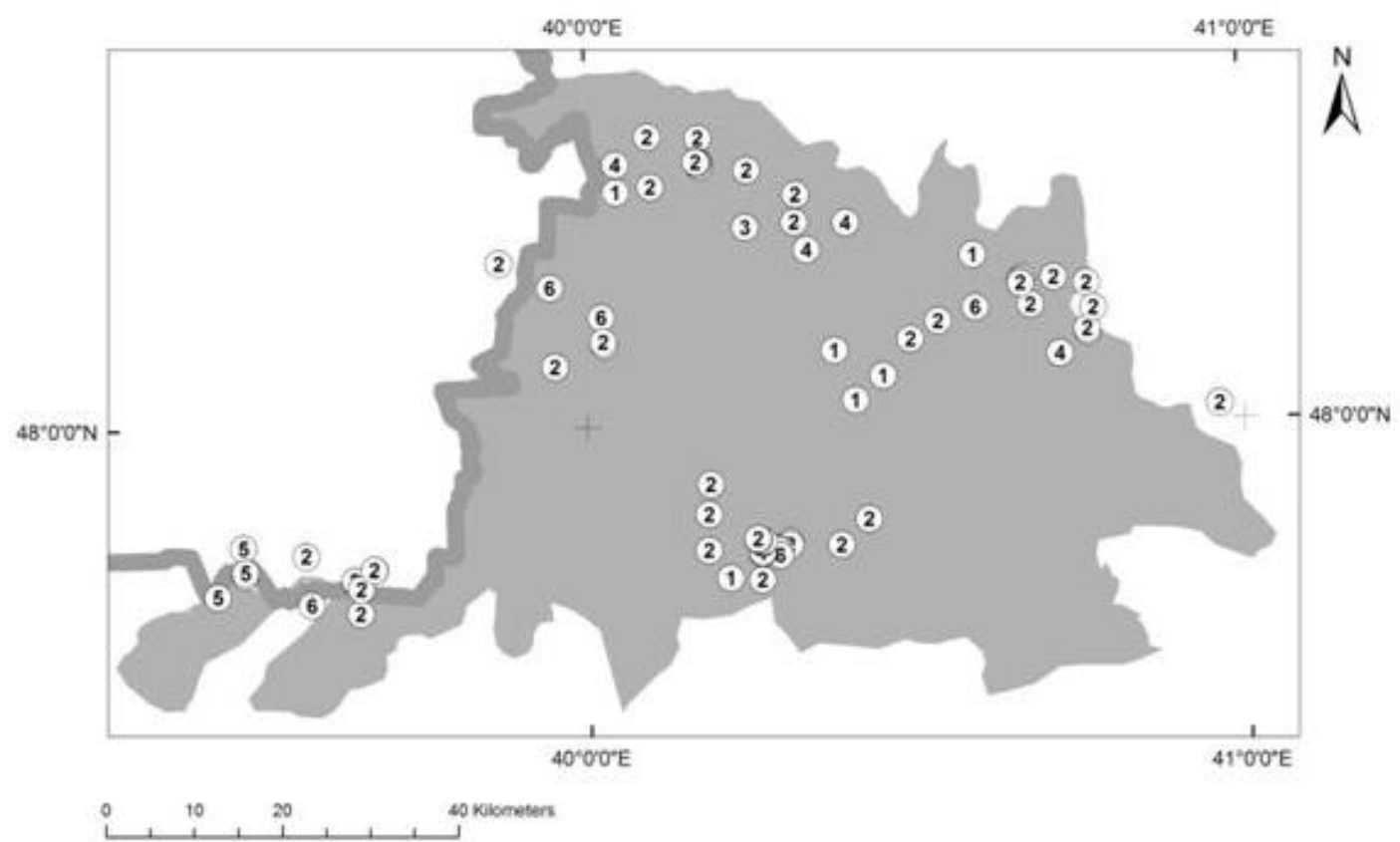

Fig. 2: Demarcation of the communities of plant associations identified in the Donets Ridge area (Digits denote the following associations:1 - Plantagini urvilei - Stipetum tirsae; 2 - Stipetum lessingianae; 3 - Plantagini stepposae - Stipetum pulcherrimae; 4 -Medicago romanicae-Stipetum zalesskii; 5 - Sileno borysthenicae - Hyssopetum angustifolii; 6 - Scleranto annui - Stipetum capillatae)

Grades (indices) of the species occurrence: I - single or rare occurrence (the species described in a single or a low number of reference sources); II - rare or very rare occurrence (low persistance: from + to I); III - sporadically (medium persistance); IV - regular occurrence (medium or high persistance); V - highest occurrence (occurred anywhere with the highest persistence).

\section{Discussion}

Petrophytic serial communities where the ecotonic effect was most strongly expressed were: Stipetum lessingianae, Medicago romanicae - Stipetum zalesskii, Plantagini urvillei Stipetum tirsae, Sclerantho annui - Stipetum capillatae (all belong to the class Festuco Brometea) as well as to the petrophytic association Sileno borysthenicae - Hyssopetum angustifolii, associations included in the class Festuco-Brometea and petropytic associations Sileno borysthenicae - Hyssopetum angustifolii.

The highest index of the floristic-phytosociological significance (F1) was found for the association Sileno borysthenicae - Hyssopetum angustifolii included in the class HelianthemoThymetea.

A scheme of key areas important for the design of transport and functional ecological corridors located at the Russian-Ukrainian border (cross-border level of environmental networking) is shown in Fig. 3. These corridors play a meaningful role in creating the specially protected natural areas in studied territories. 
Table 2: Phytocenotic demarcations of the rare and endangered plant species included in the Red Books of the Rostov Region and Russian Federation.

\begin{tabular}{|c|c|c|c|c|c|c|}
\hline \multirow[t]{2}{*}{ Class } & \multicolumn{5}{|c|}{ Festuco-Brometea } & \multirow[b]{2}{*}{ 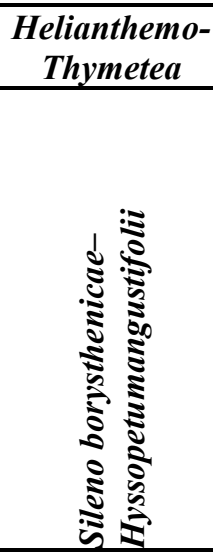 } \\
\hline & 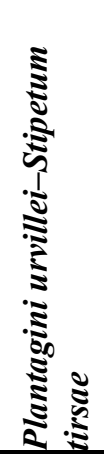 & 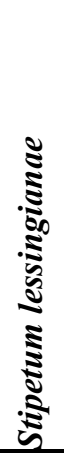 & 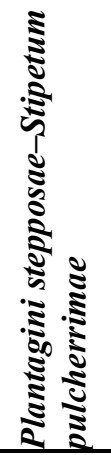 & 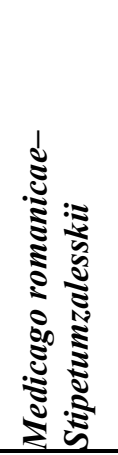 & 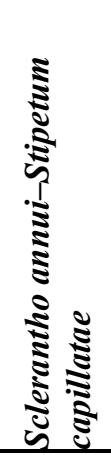 & \\
\hline Number of test plots & 11 & 16 & 2 & 10 & 17 & 3 \\
\hline Bellevalia sarmatica* & 3 & 2 & 2 & 1 & 1 & . \\
\hline Stipa ucrainica & 1 & 1 & . & 5 & 1 & . \\
\hline Stipa zalesskii* & 3 & 3 & . & 3 & 3 & . \\
\hline Tulipa biebersteiniana & 1 & 1 & . & 1 & 1 & . \\
\hline Stipa pulcherrima* & 4 & . & 5 & 1 & . & . \\
\hline Stipa dasyphylla* & 5 & . & . & 3 & 1 & . \\
\hline Iris pumila* & & 1 & . & 1 & 2 & . \\
\hline Stipa pennata* & 3 & . & . & 1 & . & . \\
\hline Thymus calcareus & & & . & & 1 & 5 \\
\hline Stipa tirsa & 4 & . & . & 1 & . & . \\
\hline Centaurea ruthenica & 1 & . & . & . & . & . \\
\hline Asperula tephrocarpa & . & . & . & . & 2 & . \\
\hline Astragalus calycinus & . & . & . & . & 1 & . \\
\hline Elytrigia stipifolia* & . & . & . & 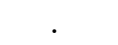 & . & 4 \\
\hline Campanula macrostachya & 3 & . & . & . & . & . \\
\hline Cotoneaster alaunicus* & . & . & . & . & 1 & . \\
\hline Ventenata dubia & . & & . & & 1 & . \\
\hline Crambe tataria & . & 1 & . & & . & . \\
\hline Tulipa gesneriana & . & 1 & . & & . & . \\
\hline Pulsatilla pratensis & & 1 & & & & \\
\hline Total & 10 & 8 & 2 & 9 & 11 & 2 \\
\hline
\end{tabular}

* Species included in the Red Book of Russian Federation [54]

Five associations of high environmental protection significance have been selected when evaluating the floristic-phytosociological significance of the studied communities. They are: Stipetum lessingianae, Medicago romanicae - Stipetum zalesskii, Plantagini urvillei-Stipetum tirsae, Sclerantho annui - Stipetum capillatae, Sileno borysthenicae-Hyssopetum angustifolii. This suggests that the territories occupied by these communities should be considered as key territories at the national, regional, and local levels of development of the Rostov Region ECONET (Fig. 2, 3).

At the same time it should be noted that the association Plantagini stepposae - Stipetum pulcherrimae, being of moderate floristic-phytosociological significance (F3), was not considered at the current level of analysis because of a small, non-representative sampling, and, therefore, cannot be evaluated from the environmental protection point of view. 


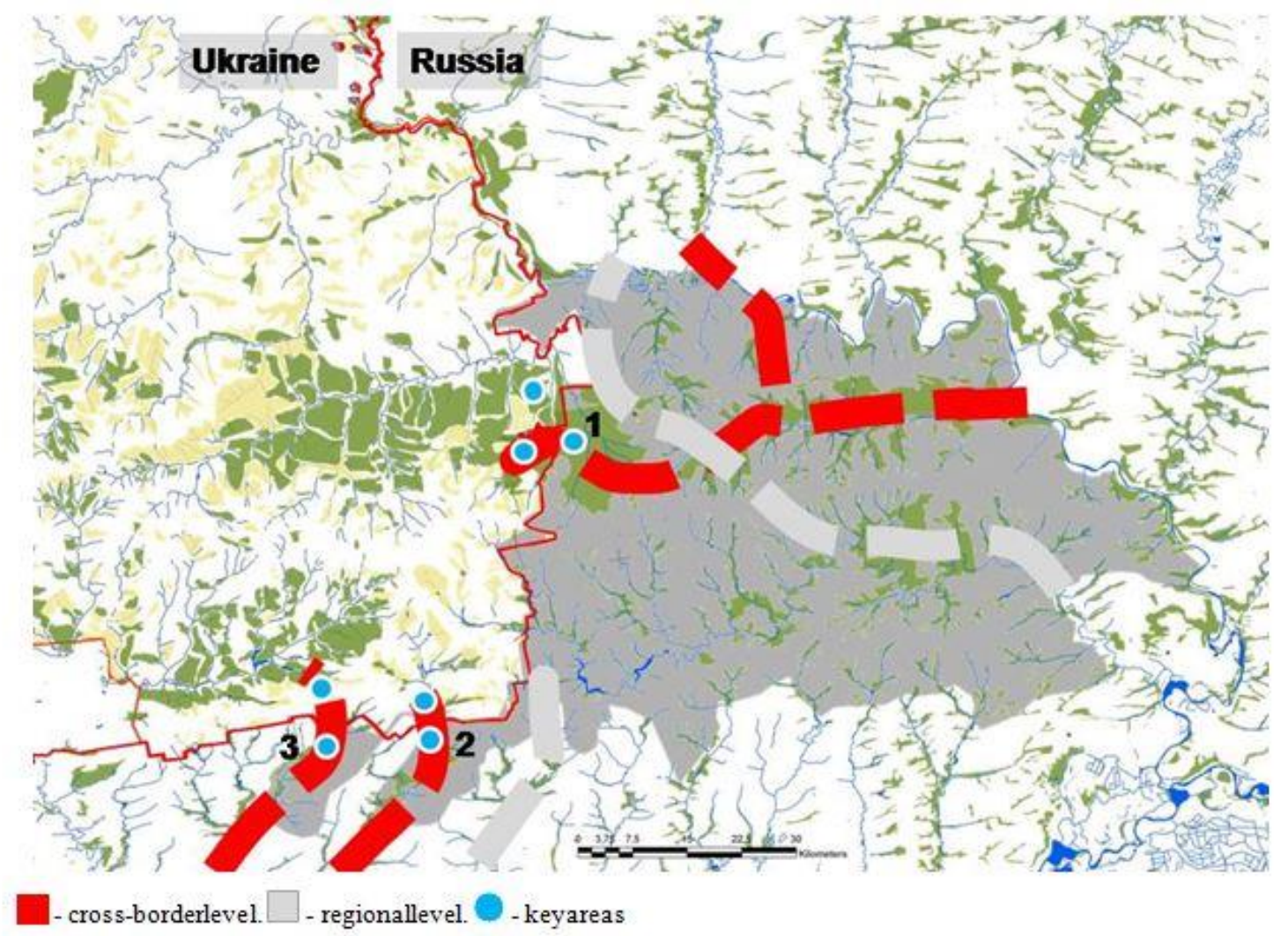

Fig. 3: Transport and functional ecological corridors, key ECONET areas at Donets Ridge

Results of our work have shown, that five associations, viz. Stipetum lessingianae, Medicago romanicae - Stipetum zalesskii, Plantagini stepposae - Stipetum pulcherrimae, Plantagini urvillei-Stipetum tirsae, Sclerantho annui-Stipetum capillatae included in the class Festuco-Brometea and association Sileno borysthenicae - Hyssopetum angustifolii (class Helianthemo-Thymetea), may be distinguished within the Donets Ridge region as a result of the ecological-floristic classification carried out.

The key territories within that the studied communities of five associations (Stipetum lessingianae, Medicago romanicae - Stipetum zalesskii, Plantagini urvillei - Stipetum tirsae, Sclerantho annui - Stipetum capillatae, Sileno borysthenicae - Hyssopetum angustifolii) are described, should be considered as the most significant structural cross-border elements of the project of a Pan-European Ecological Network. All of them represent the steppe petrophytic vegetation of the Donets Ridge.

\section{Conclusions}

Ecological-floristic classification is a subject of great importance when evaluating floristicphytosociological and environmental significance of the studied communities. Also it is an important tool for the inventory of the potential protected objects and for the development of recommendations to improve their territorial protection within the general system of steppe zone biodiversity conservation.

Key areas within the boundaries of which the studied communities of the five associations are described and which represents steppe petrophytic vegetation should be considered as influential structural transboundary elements in the Pan-European Ecological Network project. 
The developed recommendations to improve protection of plant communities of Donets Ridge are that the protection of the existing specially preserved natural areas should be enhanced as well as that new protected areas should be established.

Acknowledgments: The research was performed with the equipment of Multiaccess Center 'Biotechnology, biomedicine and environmental monitoring' and Multiaccess Center 'High technologies' of Southern Federal University (Rostov-on-Don).

Funding: The research was financially supported by the Ministry of Science and Higher Education of the Russian Federation within the framework of the state task in the field of scientific activity (no. 0852-2020-0029).

\section{REFERENCES}

1. Braun Blanquet, J., 1964, Pflanzensociologie, Grundzuge der Vegetationskunde, 3 Aufl. Wien.

2. Cheshev, A.S., Tsvylev, E.M., Klimenko, G.G., Burlakov, N.P., Klimenko, G.V., Zemlyanov, A.N., Borisenko, A.N., Tarasov, A.S., 1991, Economic assessment of agricultural lands of the Rostov region, Rostov-on-Don, $240 \mathrm{pp}$.

3. Clarke, K.R., 1993, Non-parametric multivariate analyzes of changes in community structure, Australian Journal of Ecology, 18: 117-143.

4. Demina, O.N., Rogal, L.L., Kupryushkin, D.P., 2010, Assessment of the environmental significance of the communities of the Plantaginistepposae - Stipetumpulcherrimaestipetosumzalesskiisubasssubassociation. nov. prov. IV Scientific and Practical Conference "Museum-Reserve: Ecology and Culture", pp. 28-31.

5. Demina, O.N., 2007, Formation of a system of natural monuments in the Rostov region, Moscow - Rostov-onDon.

6. Demina, O.N., 2008, Steppes of the Don basin within the Rostov region, XII Congress of the Russian Botan. about - va. "Fundamental and applied problems of botany at the beginning of the XXI century," Materials of the All-Russian Conf. (Petrozavodsk, 22-27 September 2008), pp. 80-83.

7. Demina, O.N., 2011, Regularities of distribution and development of the vegetation cover of the Don basin steppes (within the boundaries of the Rostov region), Abstract of the thesis for the degree of Doctor of Biological Sciences. Moscow.

8. Demina, O.N., 2012, New associations of hyssopians and thyme steppes on the Donetsk Ridge, News of the Samara Scientific Center of the Russian Academy of Sciences, 141 (1): 998-1003.

9. Demina, O.N., 2014, Ecological model of the vegetation cover of the Don basin steppes, Electronic scientific journal "Engineering Bulletin of the Don", 2 (29): 3.

10. Didukh, Y.P., 1982, Problems of activity of plant species, Bot. zhurn., 67 (7): 925-934.

11. Dmitriev, P.A., Demina, O.N., 2013, Ordination of psammophytic vegetation of the Don's sandy massifs. Living and Biocosystems, 2: 16. http://www.jbks.ru/archive/issue-2/article-7. Accessed 11February 2021.

12. Dmitriev, P.A., 2013, Ordination of psammophytic vegetation in the river basin. Don (within the boundaries of the Rostov region), Polythematic network electronic scientific journal of the Kuban State Agrarian University (Scientific journal KubSAU), 04 (88): 10. http://ej.kubagro.ru/2013/04/pdf/39.pdf. Accessed 11 February 2021.

13. Gorbachev, B.N., 1974, Vegetation and natural forage lands of the Rostov region (explanatory text for vegetation maps), Rostov-on-Don: Rostov, book. publishing house.

14. Hennekens, S., 1996, TURBOVEG: Software package for input, processing and presentation of phytosociological data. User's guide. JBN - DLO, University of Lancaster.

15. Hill, M.O., Gauch, H.G., 1980, Detrended correspondence analysis: an improved ordination technique, Vegetatio, 42: 47-58.

16. Hill, M.O., 1979, TWINSPAN - A FORTRAN program for arranging multivariate data in an ordered two way table by classification of the individuals and attributes, Ithaca, NY: Ecology and Systematics, Cornell University. 
17. Kamelin, R.V., 2005, New flora of Altai. In: Flora of Altai 1, pp. 7-97, Barnaul: Azbuka Publishing House.

18. Korchagin, A.A., 1964, Species (floristic) composition of plant communities and methods of its study. In: Field Geobotany 3, pp. 39-62, M. - L.

19. Korolyuk, A.Y., 2007, The use of ecological scales in geobotanical research, Actual problems of geobotany. Lectures, Petrozavodsk: Karelian Scientific Center of the Russian Academy of Sciences: 177-197.

20. Kupryushkin, D.P., Dmitriev, P.A., 2015a, Ordination in the knowledge of the ecology of communities, on the example of studying the steppe vegetation of the Donetsk ridge. In: Varduni, T.V., Dmitriev P.A., Kapralova, $\mathrm{O}$. (ed.), The role of botanical gardens in the conservation and monitoring of biodiversity, Collection of materials. pp. 215-220, South Federal University. Rostov-on-Don: Publishing House of the Southern Federal University.

21. Kupryushkin, D.P., Dmitriev, P.A., 2015b, Direct ordination of the steppe vegetation of the Donetsk ridge, Young scientist, 17: 30-32.

22. Kupryushkin, D.P., Dmitriev, P.A., Demina, O.N., 2015, History of the study of petrophytic vegetation of the Donetsk ridge (review article). Polythematic network electronic scientific journal of the Kuban State Agrarian University (Scientific journal KubSAU), 08 (112): 88-98.

23. Kurepin, V.V., Abramova, T.I., 1989, Ecological - genetic rows of vegetation of stony lands of the Lower Don. In: Ecology of plants of the semi-desert and steppe zone, pp. 4-9, Elista.

24. xxx, Land resources of the North Caucasus. 1986. Rostov-on-Don: Publishing house Rost. un-ta, $288 \mathrm{p}$.

25. Lavrenko, E.M., 1926, Forests of the Donetsk Ridge (watershed between the Mius River and its right tributary, the Krvnka River), Soil Science: 3-4.

26. Lavrenko, E.M., 1950, Main features of the botanical - geographical division of the USSR and neighboring countries. In: Problems of botany, 1, pp. 530-548, M.; L.: Publishing house of the Academy of Sciences of the USSR.

27. Lavrenko, E.M., 1980a, Petrophytic vegetation in forest-steppe and steppe (outside mountain systems). In: Gribova, S.A., Isachenko, T.I.,Lavrenko, E.M. (ed.), Vegetation of the European part of the USSR, pp. 281284, L ., Nauka.

28. Lavrenko, E.M., 1980b, Edaphic variants of steppe vegetation of the Black Sea steppe province. In: Gribova, S.A., Isachenko, T.I., Lavrenko, E.M. (ed.), Vegetation of the European part of the USSR, pp. 249-254, L ., Nauka.

29. Lavrenko, E.M.,Karamysheva, Z.V., Nikulina, R.I., 1991, Steppes of Eurasia, L ., Nauka.

30. Malyshev, L.I., 1973, Floristic zoning based on quantitative traits, Bot. zhurn., 58 (11): 1581-1588.

31. Map of soil-geographical zoning of the USSR. M. 1: 8,000,000. 1986. In: Zarutskoy, I.P. (ed.), 2 p. M.

32. Marina, L.V., 2000, Intra-landscape activity of flora species of the Visimsky Reserve (Middle Urals). In: Comparative floristics at the turn of the 3rd millennium: achievements, problems, prospects, pp. 263-274, SPb., BIN RAN.

33. Martynenko, V.B., Mirkin, B.M., 2006, The role of vegetation classification in the design of a system of protected natural territories. In: Mat. International. scientific. Conf., dedicated to the 200th anniversary of the Kazan Botanical School, Questions of general botany: traditions and prospects, 2, pp. 301-303, Kazan.

34. McCune, B., Mefford, M.J., 1999, PC-ORD, Multivariate Analysis of Ecological Data, Version 4. MjM Software Design, Glended Beach, Oregon, USA.

35. Mirkin, B.M., Naumova, L.G., 1998, Science of vegetation (history and current state of the main concepts). Ufa: Gilem.

36. Mirkin, B.M., Alimbekova, L.M., Naumova, L.G., Onishchenko, L.I., 1992, The system of higher units of syntaxonomy of vegetation in Mongolia, Biol. Science, 4: 22-34.

37. Natural conditions and natural resources of the Rostov region. 2002, In: Khrusalev, Y.P. (ed.), 432 p., Rostovon-Don: Batayskoe book. publishing house.

38. Ramenskiy, L.G., Tsatsenkin, I.A., Chizhikov, O.N., Antipin, N.A., 1956, Ecological assessment of forage lands by vegetation cover. M.: Publishing house with. $-\mathrm{X}$. literature.

39. Restored vegetation map of Central and Eastern Europe. M. 1: 2500 000. 1996. In: Gribova, S.A., Neyheisla, R. (ed.), 6 p, BIN RAN.

40. Seledets, V.P., 1962, Stony steppes of the Donetsk ridge in the Belokalitvensky district of the Rostov region. Mater. XV student scientific conference of RSU, Rostov-on-Don. 
41. Seledets, V.P., 1964, Stony steppes of the Rostov region. In: Program and abstracts of the scientific conference dedicated to the 100th anniversary of the birth of prof. N.I. Kuznetsova, pp. 37-39.

42. Seledets, V.P., 1965, Stony steppes of the Rostov region. In: Proceedings of the sixth scientific conference of graduate students (Series of exact and natural sciences), pp. 237-240. Publishing house of Rostov University.

43. Seledets, V.P., 1966, Stony steppes of the Rostov region and their economic use. In: Abstracts of the II scientific session, biology-soil section, pp. 83-84, Rostov-on-Don.

44. Sereda, M.M., 2003, Syntaxonomy of petrophytic steppes of the Don River basin: Author's abstract. dis. ... Cand. biol. sciences. Stavropol, 19 p.

45. Soil map of Rostov region. M. 1: 3 00000. 1985. In: Tsvyleva, E.M. (ed.), 4 p. Kiev.

46. The strategy of conservation of the Russian steppes: the position of non-governmental organizations. 2006. 36 p. Moscow: Publishing House of the Center for Wildlife Conservation.

47. Tsvylev, E.M., 1988, Soil resources and some directions of development of the soil cover of the Rostov region, Izvestia SKNTs VSh, Natural sciences, 4: 3-8.

48. Vegetation map of the Rostov region. Rostov-on-Don. M. 1: 800 000. 2005. In: Demina, O.N., Mokrievich, V.I., Tsvylev, E.M., Kirilenko, Z.V. (ed.), 2 p.

49. Weber, H.E., Moravec, J., Theurillat, J.-P., 2000, International Code of Phytosociological Nomenclature 3rd edition, J. Veget. Sci., 11 (5): 739-768.

50. Zozulin, G.M., 1992, Forests of the Lower Don, Rostov-on-Don: Publishing House of Rostov University.

51. Zverev, A.A., 2007, Information technologies in vegetation research, Tomsk.

52. Yatsuta, K.Z. et al., 1940, Natural areas of Rostov region. Rostov-on-Don, Rostov Regional Book Publishers, (in Russian).

53. Tichý, L., Holt, J., JUICE, Program for management, analysis and classification of ecological data. Program manual. 2006. pp. 103 p. http://www.sci.muni.cz/botany/juice/JUICEman_all.pdf.

54. Red Book of Russian Federation (Plants and Fungi). Moskow, Scientific Publishers Association KMK, 2008, pp 855, (in Russian).

55. Unatov, A.A., Types and content of geobotanical studies. Selection of sampling areas and creation of ecological profiles. // Field geobotany, in 3 Volumes, Moskov, St-Petersburg, 1964, P. 9-36 (in Russian).

\section{VEGETAȚIA PETROFITICĂ A CRESTEI DONETS}

\section{(Rezumat)}

Au fost descrise habitate vegetale unice pentru comunităţile petrofitice ale crestei Donets. A fost propusă o bază științifică pentru conservarea vegetaţiei zonale de stepă împreună cu variantele petrofitice, utilizând ca exemplu un număr de comunităţi petrofitice caracteristice crestei Donets. S-au propus mai multe criterii de importanță a conservării pentru a evalua motivele includerii teritoriilor naturale în lista obiectivelor protejate. S-au făcut şi recomandări pentru îmbunătățirea protecției vegetației petrofitice de stepă a crestei Donets. De asemenea, s-au formulat și propuneri pentru crearea unei rețele ecologice în cadrul zonei studiate. 